\title{
Effect of Aluminium Content on the Tensile Properties of Mg-Al-Zn Alloys
}

\author{
(Kesan Kandungan Aluminium Terhadap Sifat Tegangan Bagi Aloi Mg-Al-Zn) \\ N. Abdul Latif*, Z. Sajuri \& J. Syarif
}

\begin{abstract}
The aim of this study is to investigate the effect of aluminium content on microstructure, tensile properties and work hardenability of Mg-Al-Zn alloys. Two types of magnesium alloys were investigated i.e. AZ31 and AZ61, where the aluminium contents were $3 \%$ and $6 \%$, respectively. Microstructure observation revealed that higher aluminium content decreases the grain size and increases the volume of $\mathrm{Mg}_{1} \mathrm{Al}{ }_{12}$ precipitations. From the tensile test, AZ61 demonstrated higher yield stress and tensile strength while maintaining the elongation as compared to AZ31. The work hardening rate for AZ61 was also greater as compared to that of AZ31.
\end{abstract}

Keywords: Magnesium alloys; aluminium content; microstructure; tensile properties; work hardening

ABSTRAK

Tujuan kajian ini adalah untuk mengkaji kesan kandungan aluminium pada mikrostruktur, sifat tegangan dan kebolehkerasan kerja bagi aloi Mg-Al-Zn. Dua jenis aloi magnesium telah dikaji iaitu AZ31 dan AZ61, di mana kandungan berat aluminium masing-masing adalah 3\% dan 6\%. Pemerhatian mikrostruktur menunjukkan bahawa kandungan aluminium yang tinggi dapat mengurangkan saiz ira dan meningkatkan jumlah mendakan $\mathrm{Mg}_{1} \mathrm{Al}_{12}$. Daripada ujian tegangan, AZ61 menunjukkan tegasan alah dan kekuatan tegangan yang lebih tinggi serta mengekalkan pemanjangan apabila dibandingkan dengan AZ31. Kadar kerja pengerasan bagi AZ61 juga lebih tinggi berbanding AZ31.

Kata kunci: Aloi magnesium; kandungan aluminium; mikrostruktur; sifat tegangan; kerja pengerasan

\section{INTRODUCTION}

In recent years, magnesium alloys are widely used as structural materials in automotive industry due to the combination of low density, high strength properties and good machinability (Blawert et al. 2004; Gaines et al. 1995). Excellent mechanical properties of magnesium alloys have attracted engineers' attention to choose these alloys for engineering structures but so far the application in major load bearing components in which reliability, durability and safety are of major concern is still very limited. One of the most popular magnesium alloys used in automotive and industry are the $\mathrm{Mg}-\mathrm{Al}-\mathrm{Zn}$ alloy series i.e. AZ31, AZ61 and AZ90. These alloys are now becoming the premier choices for light weight application due to their improved mechanical properties with addition of certain percentage of aluminium and zinc (Marya et al. 2006).

Addition of aluminium as an alloying element in magnesium alloys is very important for high precipitation density of $\mathrm{Mg}_{17} \mathrm{Al}_{12}$ phase. This $\beta-\mathrm{Mg}_{17} \mathrm{Al}_{12}$ will act as strengthening phases that increase the tensile strength of magnesium alloys. Beside aluminium, the addition of zinc will also affect the strengthening of magnesium alloy (Cheng et al. 2009; Kainer 2003; Marya et al. 2006). However, the different composition of aluminium and zinc elements in $\mathrm{Mg}-\mathrm{Al}-\mathrm{Zn}$ alloy series could results in different mechanical properties especially the work hardenability and the tensile properties. In present study, effect of aluminium content on microstructure, tensile properties and work hardenability of constant $\mathrm{Zn}$ content in $\mathrm{Mg}-\mathrm{Al}-\mathrm{Zn}$ alloys were investigated.

\section{EXPERIMENTAL PROCEDURE}

The materials used in this study were extruded AZ31 and AZ61 of the Mg-Al-Zn alloy series. The two letters followed by two numbers designate the name of the magnesium alloys. The two letters tell the main alloying elements ( $\mathrm{A}$ is for aluminium and $\mathrm{Z}$ is for zinc). The numbers tell the nominal compositions of main alloying elements respectively. Detail chemical compositions of AZ31 and AZ61 being used in this study are listed in Table 1.

TABLE 1. Chemical composition of AZ31 and AZ61

\begin{tabular}{ccccccccc}
\hline & $\mathrm{Al}$ & $\mathrm{Zn}$ & $\mathrm{Mn}$ & $\mathrm{Fe}$ & $\mathrm{Si}$ & $\mathrm{Cu}$ & $\mathrm{Ni}$ & $\mathrm{Mg}$ \\
\hline Az31 & 3.35 & 0.88 & 0.33 & 0.003 & 0.01 & $<0.002$ & $<0.002$ & Bal. \\
Az61 & 5.84 & 0.65 & 0.29 & 0.002 & 0.01 & 0.001 & 0.0003 & Bal. \\
\hline
\end{tabular}

Both alloys were polished and etched to reveal their microstructure. They were then observed under the optical microscope. To obtain the mechanical properties of the 
magnesium alloys, tensile tests were performed on dumb-bell shaped specimens with a gage length and gage diameter of $10 \mathrm{~mm}$ and $3 \mathrm{~mm}$, respectively. Tensile test was conducted using the Universal Testing Machine with a capacity of 100 $\mathrm{kN}$ at strain rate of $1 \times 10^{-3} \mathrm{~s}^{-1}$ in room temperature. Detail stress-strain responses were recorded using a data acquisition system. Further analyses of work hardening behavior for both alloys were performed and identified by using the following equations (1) to (3).

$$
\sigma=\frac{F}{A_{T}}
$$

where, $\sigma$ is the true stress, $F$ is the force and $A_{T}$ the area of cross section at the force, $F$ and the true strain $\varepsilon$ is defined as:

$$
\varepsilon=\ln \left(1+\frac{\mathrm{d} L}{L_{O}}\right)
$$

where $d L$ is the elongation and $L_{O}$ the original gage length. The work hardening rate is given as:

$$
\frac{\mathrm{d} \sigma}{\mathrm{d} \varepsilon}=\frac{\sigma_{2}-\sigma_{1}}{\varepsilon_{2}-\varepsilon_{1}}
$$

where $d \sigma$ is the increment of true stress and $d \varepsilon$ the increment of true strain.

\section{RESULT AND DISCUSSION}

\section{MICROSTRUCTURE}

Figure 1 shows the microstructures of AZ31 and AZ61 observed under the optical microscope. From the figure, it shows that both alloys have an equiaxed grain structure. The average grain size of AZ31 and AZ61 were $24 \mu \mathrm{m}$ and $15 \mu \mathrm{m}$ as shown in Figure 2.

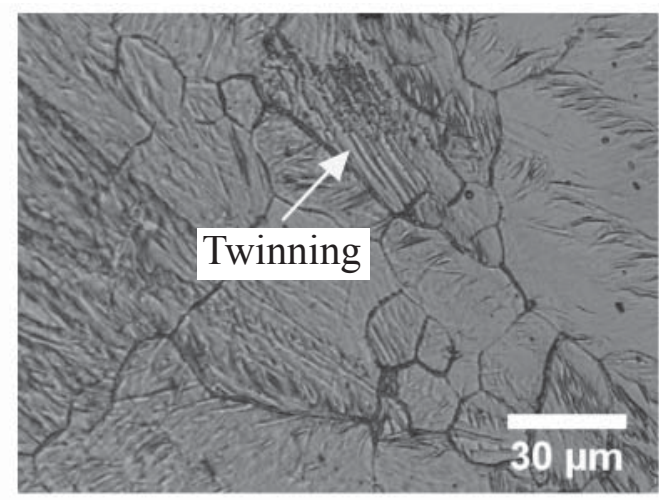

(a)

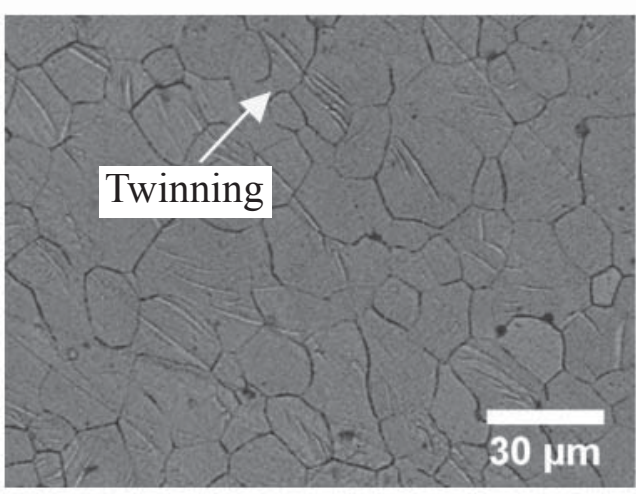

(b)

FIGURE 1. Microstructure of (a) AZ31 and (b) AZ61

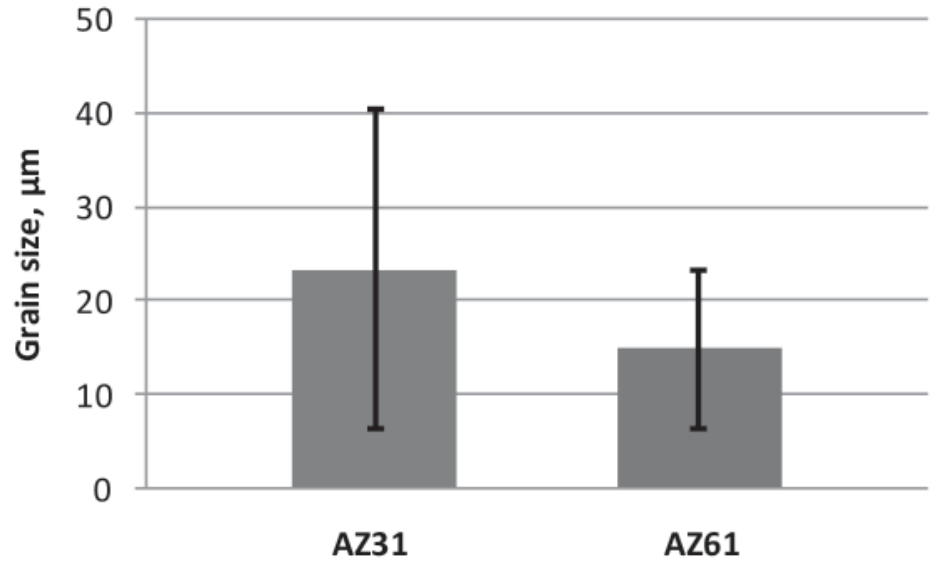

FIGURE 2. Average grain sizes of AZ31 and AZ61 
From Figure 1, it is clearly seen that the AZ31 has a larger grain size compared to that of the AZ61. Microstructure of AZ31 as shown in Figure 1(a) indicated more twinning, as indicated by the arrow, which probably due to the extrusion process while, less twinning for Az61 as shown in Figure 1(b). Higher density of twinning was observed in AZ31 which had a larger grain size compared to that of the AZ61. Twinning formation is assumed to be resulted from the extrusion process as stated by Barnett (2007a) (Barnett 2007b). For AZ61 as in Figure 1(b), it is assumed that more precipitates in the alloy pinned the twinning formation so that less twinning was observed compared to that in AZ31.

The smaller grain size and higher density of $\mathrm{Mg}_{17} \mathrm{Al}_{12}$ precipitation in AZ61 are believed to be caused by higher aluminium content that formed the solid solution in the alloy (Kainer 2003, St John et al. 2005). The $\mathrm{Mg}_{17} \mathrm{Al}_{12}$ precipitation observed in Az61 is shown in Figure 3. Sajuri (2005) mentioned that during the extrusion process of magnesium alloys, the casting defects will almost disappear when as-cast alloy heated to $350-400^{\circ} \mathrm{C}$ and squeezed through an extrusion die. SEM observation showed that after the extrusion process, the $\beta$ - $\mathrm{Mg}_{17} \mathrm{Al}_{12}$ phase in Az61 alloy was almost completely dissolved and there was no casting defects presented in the matrix (Sajuri 2005). On the other hand, the existence of twinning in a material would also contribute to higher flow stress and better work hardening (Yablinsky et al. 2006). However, in most magnesium alloy series, finer grain size and $\mathrm{Mg}_{17} \mathrm{Al}_{12}$ precipitation have more influenced to improve the strength, work hardening and ductility despite of the smaller grain size would be suppression the twinning (Barnett 2007; Khan et al. 2006).

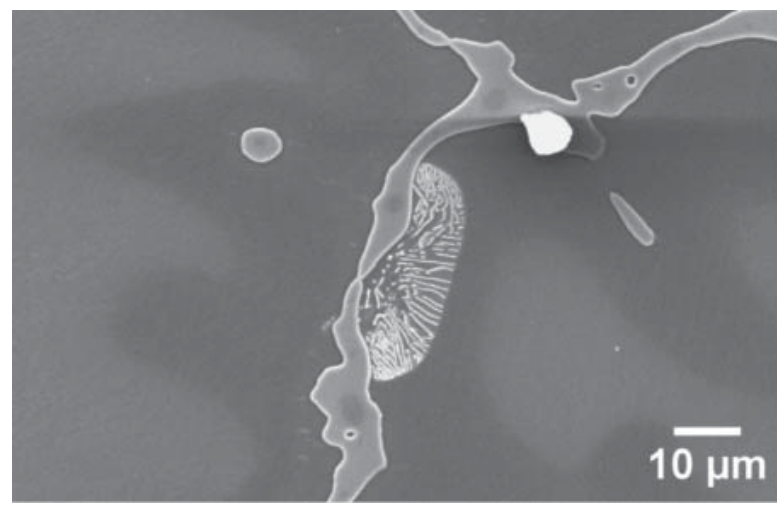

FIGURE 3. The $\mathrm{Mg}_{17} \mathrm{Al}_{12}$ precipitation of AZ61

\section{TENSILE TEST AND WORK HARDENING}

Figure 4 shows nominal stress-strain curves of AZ31 and AZ61 magnesium alloys. The result shows that AZ61 exhibited higher tensile strength and better work hardening as compared to that of the AZ31, which caused by the grain size reduction and $\mathrm{Mg}_{17} \mathrm{Al}_{12}$ precipitation. Khan et al. (2006) and Ryu et al. (2000) have reported that the higher tensile strength was due to the effects of smaller grain size and higher density of precipitation (Khan et al. 2006, Ryu et al. 2000). The tensile properties of AZ31 and AZ61 were summarized in Table 2. Yield stress and ultimate tensile strength of AZ61 were higher than that of AZ31 with $14.7 \%$ and $36.3 \%$, respectively. More work hardening of Az61 could be recognised by the large increment of differences between yield stress and ultimate tensile strength in nominal stress-strain curve. On the contrary, AZ31 clearly possessed less work hardening compare to AZ61 (Latif et al. 2014). However, the elongation for both AZ31 and Az61 were found identical.

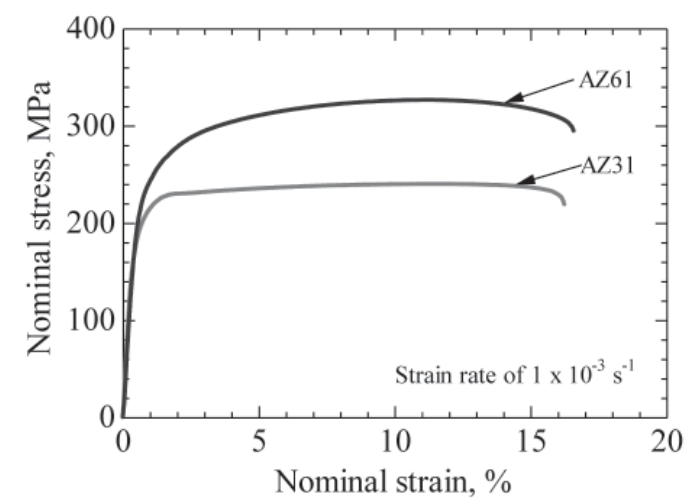

FIGURE 4. Nominal stress-strain curves of AZ31 and AZ61

TABLE 2. Tensile properties of AZ31 and AZ61

\begin{tabular}{lccc}
\hline & $\sigma_{y}(\mathrm{MPa})$ & $\sigma_{\mathrm{UTS}}(\mathrm{MPa})$ & $\varepsilon(\%)$ \\
\hline $\mathrm{AZ31}$ & 191 & 240 & 16.2 \\
$\mathrm{AZ61}$ & 219 & 327 & 16.6 \\
\hline
\end{tabular}

Work hardening rate for AZ31 and AZ61 were clearly shows in Figure 5. It is noted that the work hardening rate for AZ61 was greater compared to that of AZ31 due to the existence of precipitation and finer grain size of alloy. These

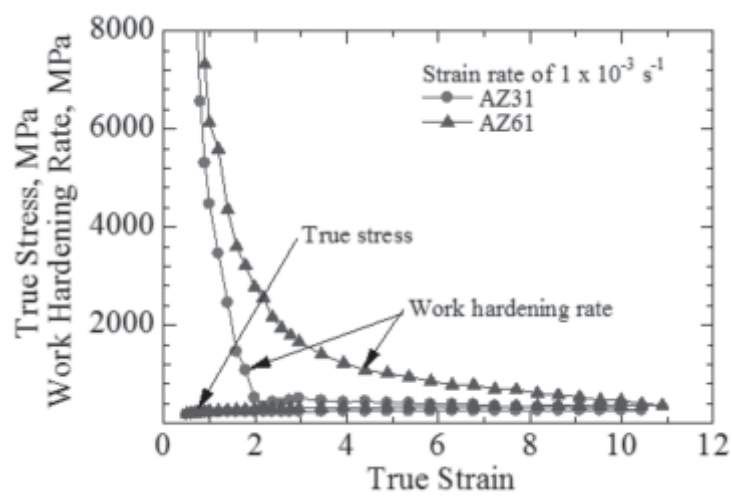

FIGURE 5. Work hardening rate of AZ31 and AZ61 
factors have influenced to the dislocation piles up against the microstructure for delayed fracture. Work hardening rate for AZ61 was considered after yielding up to the ultimate tensile strength, while the hardening process for AZ31 was diminished after yielding. The difficulty of deformation would be induced by the presence of dislocation density to allow more hardening of the alloy (Latif et al. 2014).

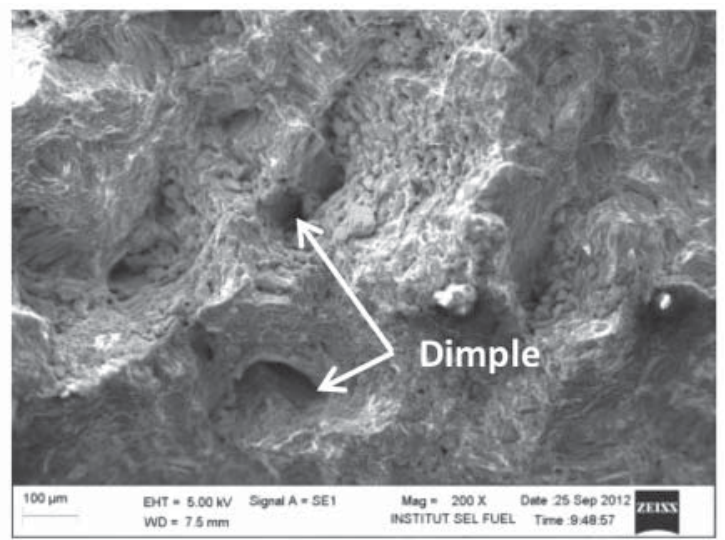

(a)

\section{FRACTURE SURFACE}

Figure 6 shows the fracture surface of AZ31 and AZ61. Both alloys clearly show ductile fracture behaviour where many dimples observed on the fracture surface. Similar observation was reported by Marya et al. (2006). However, fracture surface of AZ61 as shows in Figure 6(b) indicated more ductile fracture behaviour where more dimples and micro voids present in the fracture surface than that of AZ31 at Figure 6(a).

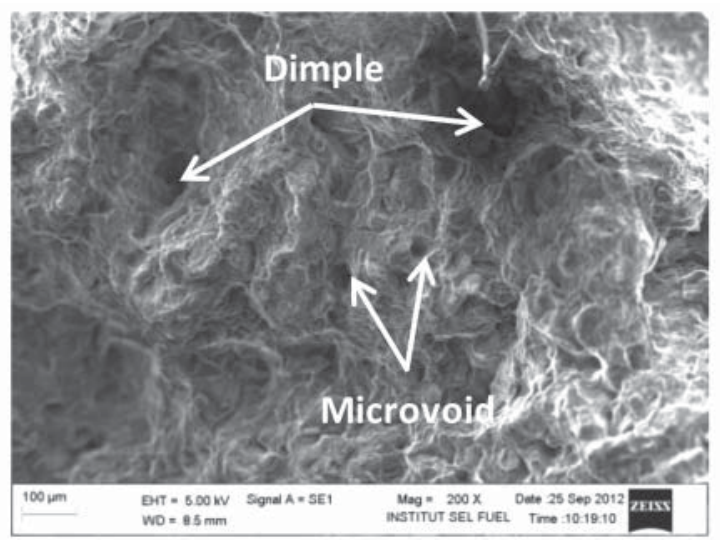

(b)

FIGURE 6. Fracture surface of (a) AZ31 and (b) AZ61

\section{CONCLUSION}

Aluminium content in $\mathrm{Mg}-\mathrm{Al}-\mathrm{Zn}$ alloy series influenced the microstructure, grain size and precipitation of $\mathrm{Mg}_{17} \mathrm{Al}_{12}$ phase. The grain size refinement and precipitation increases tensile strength and allow for more work hardening of the alloy due to more dislocation piles up and blocked at the grain boundaries before further deformation of the material. AZ61 exhibited better tensile properties than that of AZ31 with the yield stress and ultimate tensile strength of $14.7 \%$ and $36.3 \%$, respectively. However, both AZ31 and AZ61 fractured in ductile manner with more dimples and microvoids in fracture surfaces.

\section{ACKNOWLEDGEMENT}

The authors acknowledge the supports from the Universiti Kebangsaan Malaysia, Ministry of Higher Education Malaysia (ERGS/1/2011/TK/UKM/02/9), Nagaoka University of Technology, Universiti Tun Hussein Onn Malaysia and Fuel cell Institute, Universiti Kebangsaan Malaysia.

REFERENCES

Barnett, M. R. 2007b. Twinning and the ductility of magnesium alloys Part II. "Contraction" twins. Materials Science and Engineering A 464: 8-16.
Barnett, M. R. 2007a. Twinning and the ductility of magnesium alloys. Part I: "Tension" twins. Materials Science and Engineering A 464 1-7.

Blawert, C., Hort, N. \& Kainer, K. U. 2004. Automotive applications of magnesium and its alloys. Trans. Indian Inst. Met. 57: 397-408.

Cheng, Y.-L., Qin, T.-W., Wang, H.-M. \& Zhang, Z. 2009. Comparison of corrosion behaviors of AZ31, AZ91, AM60 and ZK60 magnesium alloys. Transactions of Nonferrous Metals Society of China 19: 517-524.

Gaines, L., Cuenca, R., Stodolsky, F. \& Wu., S. 1995. Potential applications of wrought magnesium alloys for passenger vehicles. $A T D-C C M$

Kainer, K. U. 2003. The current state of technology and potential for further development of magnesium applications. In Magnesium-Alloys and Technologies, edited by K. U. Kainer. Germany: Wiley-vch, Germany.

Khan, S. A., Miyashita, Y., Mutoh, Y. \& Sajuri, Z. B. 2006. Influence of Mn content on mechanical properties and fatigue behavior of extruded $\mathrm{Mg}$ alloys. Materials Science and Engineering: A 420: 315-321.

Latif, N. A., Sajuri, Z., Syarif, J. \& Mutoh, Y. 2014. Effect of strain rates on tensile strength and work hardening for Al-Zn magnesium alloys. In Recent Trends in Nanotechnology and Material Science, edited by G.F. Lumban and W. Jeffrey, 77-91. Springer. 
Marya, M., Hector, L. G., Verma, R. \& Tong, W. 2006. Microstructural effects of AZ31 magnesium alloy on its tensile deformation and failure behaviors. Materials Science and Engineering A 418: 341-356.

Ryu, H. J., Baik, H. K. \& Hong, S. H. 2000. Effect of thermomechanical treatments on microstructure and properties of $\mathrm{Cu}$-base leadframe alloy. Journal of Materials Science 35: 3641-3646.

Sajuri, Z. 2005. Study on Fatigue Behavior of Magnesium Alloys. Nagaoka: Nagaoka University of Technology, Japan, Nagaoka.

St. John, D. H., Qian, M., Easton, M. A., Cao, P. \& Hildebrand, Z. 2005. Grain refinement of magnesium alloys. Metallurgical and Materials Transactions $A$ 36A: 1669-1679.

Yablinsky, C. A., Cerreta, E. K., Gray, G. T., III, Brown, D. W. \& Vogel., S. C. 2006. The effect of twinning on the work-hardening behavior and microstructural evolution of hafnium. Metallurgical and materials transactions $A$ 37: 1907-1915.

\section{N. Abdul Latif*, Z. Sajuri \& J. Syarif}

Department of Mechanical and Materials Engineering Faculty of Engineering and Built Environment

Universiti Kebangsaan Malaysia

43600 UKM Bangi, Selangor D.E.

Malaysia

*Corresponding author; email: noradila.abdlatif@gmail. com

Received date: $21^{\text {st }}$ April 2014

Accepted date: $22^{\text {nd }}$ August 2014 
